\title{
Marcello the Dog and More-Than-Human Family in Elina Brotherus's Self-Portraits from the Series Carpe Fucking Diem
}

\author{
TIINA SALMIA \\ School of History, Culture and Arts Studies \\ University of Turku, Finland \\ tiina.salmia@utu.fi
}

\begin{abstract}
This article examines the possibilities of visual culture to open new perspectives on interspecies relations by analyzing self-portraits from visual artist Elina Brotherus's photography series Carpe Fucking Diem (2011-2015). Brotherus has suggested that this series talks "about a failure to have a family with kids and give normality the finger". The self-portraits can be seen to address this "failure" to have a normative nuclear family, while simultaneously questioning the desirability of the norm itself through Brotherus's relationship with her pet dog, dachshund Marcello. The article explores the more-than-human notions of kinship and family in Carpe Fucking Diem, drawing on Donna Haraway's concept of companion species, as well as discussions on new materialism and posthumanism. The concept of companion species deconstructs human exceptionalism and the boundaries between human and animal, and indicates that the physical and affective co-becomings between humans and the non-human significant others co-evolve with each other in complex and asymmetrical ways. In affective and embodied readings of three self-portraits and one video work from the Carpe Fucking Diem series, I examine how Elina Brotherus's self-portraits call into question the normative notions of family as human-centered and heteronormative.
\end{abstract}

KEYWORDS: agency; companion species; dog; family; non-human; self-portrait 


\section{Introduction}

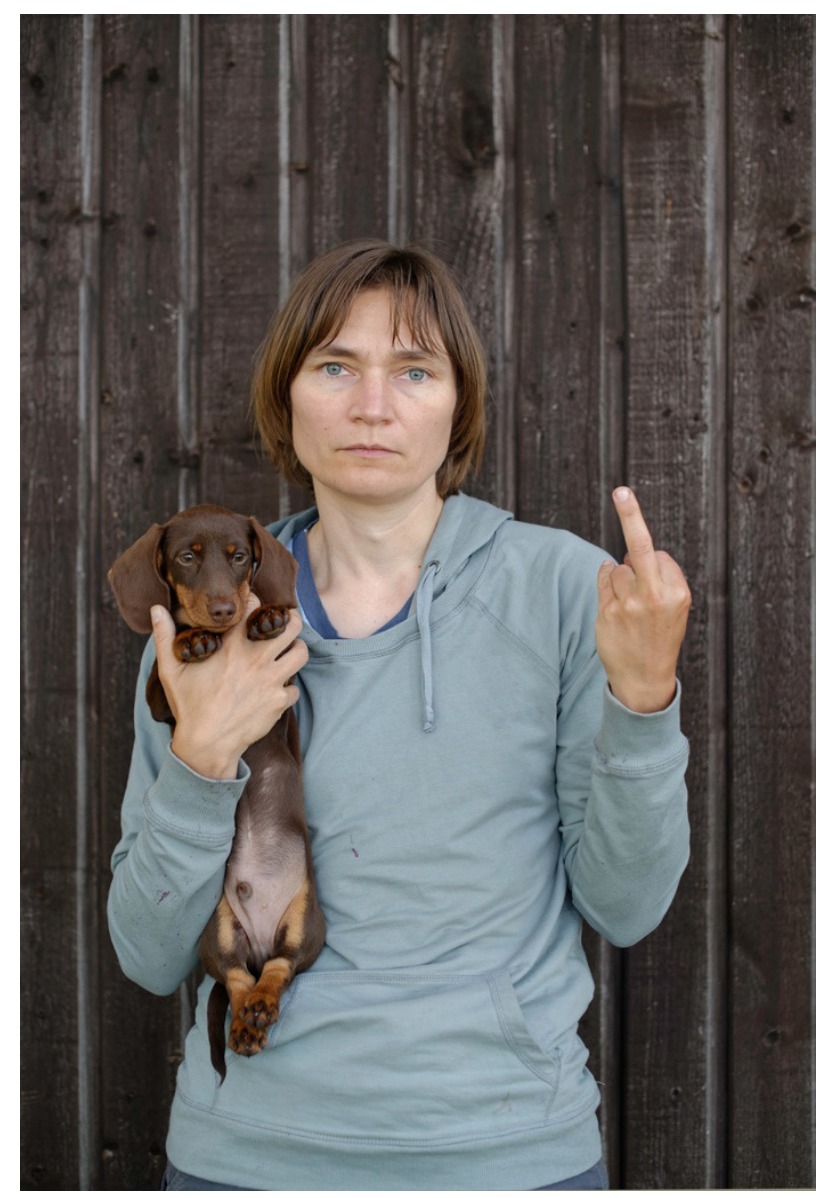

Figure 1. Elina Brotherus, My Dog Is Cuter Than Your Ugly Baby, 2013, photograph, $(80 \times 53 \mathrm{~cm})$.

Elina Brotherus's photography series Carpe Fucking Diem (2011-2015) caught my eye, as I felt it was a critique of the idea of a human-centered normative family. In the work named My Dog Is Cuter Than Your Ugly Baby (2013), the artist can be interpreted as giving family norms the finger while holding puppy Marcello. I see this as a critical family portrait commenting on the prevalence of baby pictures in social media or parodying photographs from family albums in a humorous and provocative manner. ${ }^{1}$ There are no smiles or pretty clothes chosen for the occasion and the family consists of significant others from different species. Brotherus and Marcello pose in front of a dark wooden wall. The human is looking straight into the camera and is not behaving like a normative adult in photographs, but is wearing a hoodie with stains on it and giving the viewer the

1 In fact, when I have presented early versions of this paper, seeing this photograph has caused a delighted laughter in the audience. The combination of the title and the photograph can be seen as a thought-provoking opposite to common and stereotypical family representations. 
finger. The dog looks attentive with his ears pointed forwards curiously while focusing on something outside the frame. They seem close and comfortable with each other and the comparison in the title suggests the multispecies kinship as something comparable to, or even preferable to, having a human baby.

Elina Brotherus (b. 1972) is a Finnish contemporary artist specializing in photography and video art. Photography researcher Gilles Mora describes Elina Brotherus's works as "highly autobiographical self-portraits and landscapes, in a successful reconfiguration of what she admires most in painterly tradition" (Mora 2016). A typical feature of her oeuvre is her emphasis that she is both the artist and the model, moving fluently between the conventional subject and object positions in visual culture. Recently, Brotherus's work has been increasingly autobiographical (Mora 2016). In the Carpe Fucking Diem series, she uses self-portraiture as a way of challenging the norms of a nuclear human family and

\begin{abstract}
to talk about a failure to have a family with kids...Then one starts to look around with different eyes. I began to see the surprising and surreal undertones of the everyday life, not totally deprived of humor, because even an unhappy end is not The End. I don't have children so I don't need to adopt any preconceived role of an adult. I can give normality the finger. (Elina Brotherus webpage, n.d.)
\end{abstract}

The series includes various kinds of photographic set-ups: scenery from travels, selfportraits, playful portraits, still-lifes and images of medical equipment and treatments. Through these set-ups, the series portrays a failure to reach the norm, while simultaneously questioning the very desirability of the norm. For example, many photographs in the series address a close relationship with her pet dog, dachshund Marcello. Marcello also stars in many of the photographs on Elina Brotherus's Instagram account and he has become a social media personality with an Instagram account of his own and an article about him as "the artist's muse" (Martelius 2018) in the largest newspaper in Finland, Helsingin Sanomat. ${ }^{2}$ Brotherus made the Carpe Fucking Diem series partly at the same time with the Annonciation (2009-2013) series, which addresses the topic of involuntary childlessness and five years of unsuccessful infertility treatments (Elina Brotherus webpage n.d.).

Writing about the remarkable role that online sharing of family photographs plays today, visual culture theorists Jennifer Orpana and Sarah Parsons propose that

2 The name of Marcello's Instagram account is marcello_the_flying_dachshund. 
photography both reasserts and questions traditional notions of the nuclear family (Orpana \& Parsons 2017, 95-97). In the article "Has Instagram Fundamentally Altered the 'Family Snapshot?'” the authors argue that in addition to minor mishaps, no unhappiness or discord are represented in Instagram family photographs (Le Moignan, Lawson, Rowland, Mahoney, and Briggs 2017, 4935). Rather, parents perform good parenting in social media selfies assuring that "everything is fine here" (4936). With its visualization of the fleshy reality of interspecies subject making (Haraway 2008, 66), Brotherus's My Dog is Cuter than Your Ugly Baby is a refreshing opposite to these human-centered social media representations of families reluctant to display any conflicts.

In artistic portraits of humans, animals often play supporting roles ${ }^{3}$ and visual analysis of the images mostly concentrates on human agency (see Bright 2010, 38-43; Cumming 2010, 118-21). In this article, I examine the dog's agency in negotiations related to the family by, for example, contemplating his gestures, expressions and gaze in the photographs, and by bringing him into the center of the interpretation of the images. I have decided to use the word "he" when referring to Marcello. Using the phrase "it" rather than "she" or "he" to refer to animals would construct them as objects (Fudge 2008,87 ). Also, I will henceforth call Elina Brotherus by her forename in an attempt to create a more equal way of discussing members of a more-than-human family.

\section{Questioning family norms}

Criticizing how researchers often fail to acknowledge the diversity of families and to recognize the ideology behind the concept of the family, sociologist Jon Bernardes (1999, $23,27)$ insists "we must not define 'The Family'" and argues that "traditional views of 'The Family' have been conservative, racist, classist, and heterosexist" (Bernardes 1999, 33). Visual culture continuously represents families, and while an unquestioned human-animal boundary often conceals inherent anthropocentrism, a more diverse understanding of the family is occasionally visible. Hybrid more-than-human families (Irvine \& Cilia 2016, 7-8) are increasingly discussed in relation to the companion species concept, focused on the historical and everyday co-becomings of human and nonhuman "significant others" (Haraway 2003, 16).

3 For example, the title of one of the most well-known examples follows the modern conventions of naming pieces of art and emphasizes animals as supporting characters; Lady with an Ermine (Dama con l'ermellino, 1489-1490) by Leonardo da Vinci. Ute Hörner and Mathias Antlfinger have pointed out in their artwork Unknown Parrot with Princess (2017) the power relations involved in naming works of art (Mättö 2019, 118). 
A queer theoretical critique of family and kinship is a useful point of view for discussing non-human kinship. Queer theorists have suggested that a universal theory of kinship cannot be developed since their definitions are always in flux (see Butler 2002; Weeks 2001 et al.; Weston 1991). Dominant norms, such as heteronormativity, lead to the equation of success with, for instance, family and wealth, and the association of failure with nonreproductive lifestyles and critique (Halberstam 2011, 89). Elina, imitating the prevalent norms, describes the childless family as "a failure" in the above quote, but also as a possibility to question and to rebel against the family norm.

By reflecting on the dog-human relations in three self-portraits and a video work from the Carpe Fucking Diem series, I examine how these photographs can call into question the normative notions of the family as human-centered and heteronormative. Drawing on Donna Haraway's concept of companion species, I draw inspiration from discussions within new materialism and posthumanism that question the human as the subject and agent in opposition to nature as passive material and resource for human actions. I also take into consideration the encounters between the researcher and these works, as well as the production of knowledge as an embodied and subjective process (see Kontturi 2013, 19; Barrett 2013, 63 and Bolt 2013, 1-3). In addition to My Dog is Cuter than Your Ugly Baby (Fig. 1), I analyze the photographs entitled Silver River (2014) and Marcello's Theme (2014), as well as the video work with the same title, Marcello's Theme (2015). All of these works deal with non-human and human embodied agency and human-animal entanglements.

In addition to the self-portraits, the Carpe Fucking Diem photography series includes skin to skin photographs of Marcello and the human family-members, images of syringes (which I presume are related to infertility treatments), and portraits of humans wearing animal masks. The interconnectedness of human and animal bodies provides different conceptions of who we count as family. The mutual inter-species care and the embodied entanglements of everyday life shared with dogs in a more-than-human family, shape the dog and the human, resulting in an intertwining of their historically specific and joint lives (Haraway 2003, 16). Furthermore, authors of the article "The Family Camera Network" argue that utopian, performative and queer moments in family photographs produce alternatives to the prevalent notions of the family (Phu, Brown \& Dewan 2017, 158).

In recent decades, ideas about family and kinship, once considered natural, have been challenged. The myth of heterosexual reproduction as the signifier for family has been called into question with, for instance, the advancements in non-sexual reproduction (see Braidotti 1994, 51). Interestingly, European countries have both recog- 
nized alternative family structures and witnessed a growing emphasis on conservative family values (Dahl \& Gunnarsson Payne 2014, 11-12). Moreover, Judith Butler (2002) critically examines the deep-held belief that the origin of culture lies in heterosexuality (Butler 2002, 34-35). Nuclear family ideals can be contested, they argue, by queering kinship with complex assemblies of individuals who care for each other. Furthermore according to Butler (2002), studying reproduction and family is important, because this also means studying power relations.

In the self-portraits, the carnal and material bodies of Elina and Marcello were in front of the camera when the photographs were taken. Stacy Alaimo asserts based on the concept of intra-activity by Karen Barad (2003) and situated knowledges by Donna Haraway (1991), that agency consists of trans-corporeal interactions between the human and the natural world in which human corporality is always enmeshed in the more-than-human world, while its interactions with other bodies constantly shape it (Alaimo 2008, 238, 248-49). Posthumanist and new materialist discussions about art and literature contest representation theories, which prioritize human mind and language (Hyttinen \& Lummaa 2020, 21), and propose literature is read as embodied beings, being impressed by the text and experiencing it corporally. According to Hyttinen and Lummaa (2020, 22), occasionally literature also opens a possibility to better understand the experiences of non-human animals. I believe these same concerns apply to experiencing visual culture, such as in the works from the Carpe Fucking Diem series.

Haraway's (2003; 2008) concept of "companion species" deconstructs human exceptionalism and the boundaries between humans and animals, while elucidating the physical and affective co-becomings between the human and the non-human "significant others". To be a human being means being in a network of relations. Humans and domesticated animals co-evolved with each other in complex and asymmetrical ways (Haraway 2003; 2008). The relationship between a dog and a human is co-constitutive: there has to be at least two companion species to make one (Haraway 2003, 12). Dogs and humans have not remained unchangeable throughout their relations, rather, companion species emerged as historical beings and as subjects and objects to each other (Haraway 2008, 62). In The Companion Species Manifesto (2003) and When Species Meet (2008), Haraway writes from an embodied position of someone who is a member of "a fictive kin group in training" (Haraway 2003, 40). Inspired by her significant other, the Australian Shepherd Cayenne Pepper, she examines "whom and what do I touch when I touch my dog" (Haraway 2008, 3). Haraway attempts to understand how different agents construct worlds collectively and how nature and culture constantly 
merge into complex connections. The concept of "naturecultures" emphasizes how nature cannot be separated from culture, environment from humans, or materiality from meaning (Haraway 2008, 62; Hyvärinen et al. 2017, 2). Naturecultures offers a point of view in which human and non-human embodied agencies are attached to organic and non-organic environments (Hyvärinen et al. 2017, 2). In the Carpe Fucking Diem series, the intertwining of the human, the dog and the environment is highlighted with, for instance, colours, and to me, the non-human does not appear as a passive material to the actions of humans.

\section{The fleshy reality of living in a more-than-human family}

During the past five years, I have experienced intensely the fleshiness of living and dying in a more-than-human family. I have given birth to both of my children, suffered from severe long-term pregnancy nausea and a lack of sleep. Meanwhile, I was caring for our dog with her worsening health-issues, until finally losing this dear family member after 16 years of companionship. When I saw My Dog is Cuter than Your Ugly Baby in Helsinki's Gallery Heino in 2016, it felt like a punch in my gut. An angry and confrontational artist staring straight into my eyes with Marcello in her lap evoked mixed feelings about my recent choice to have children (and being able to realize this decision), while living within an era of climate crisis. I felt, from my subjective and embodied point of view, that this image was a celebration of multispecies kinship. My impression of the work was a critique against bringing human children into this world, a place that certainly does not need more human beings.

My powerful reaction to the photograph inspired me to write this article, to question family as a human-centered and heteronormative concept and the hierarchical relations and boundaries between different species, as well as to analyze the coconstitutive relationships between dogs and humans in which "none of the partners pre-exist the relating" (Haraway 2003, 12). In the My Dog Is Cuter Than Your Ugly Baby photograph, Elina seems to look at the institution of the family as if from the outside. I see her performing nuclear family norms by repeating them differently. A baby is replaced with a puppy, and this act is emphasized in the title of the work. This critical position questions the desirability of this norm, while the dog, as central to the family, has become something that re-makes family.

Feminist discussions about the reproductive process have deconstructed the strict division between humans and non-humans. Feminist theorist Elli Lehikoinen (2017, 21-22) argues that the "obscure experience of the reproduction process" ques- 
tions the superiority of humans in relation to other species in literature about parenthood. For many authors, to write about the reproduction process and describing the messy experiences - such as the movements of the fetus in the uterus blurring the boundaries of the subject and the object in a pregnant body - is a challenging process. These texts often depict the difficulties of representing the materiality of the world, express the blurring of divisions, and manifest new ways of considering similarities between humans and other mammals (Lehikoinen 2017, 27-31). Feminist musicologist Taru Leppänen $(2016,99-101)$ explores the relations between pregnant persons and fetuses as a constitutive relationality enabled by childbirth singing vibrations. Leppänen $(2016,101,108)$ sees music as non-human matter with agency through the concept of a vibrancy with which the singer touches their body from the inside. This emphasizes the collectivity and relationality of the body, which is "always more than one" (Leppänen 2016, 101).

The relationship between the multispecies significant others in a family is also a messy, embodied business. Haraway writes about a "multidirectional gene flow" (Haraway 2003, 12) and how she suspects the human genome contains "molecular record of the pathogens of their companion species" (Haraway 2003, 31). ${ }^{4}$ She observes that embodied communication is more like a dance than a word. The flow of entangled meaningful bodies in time is a form of communication about a relationship and the relationship itself (Haraway 2008, 26). The entanglements of the human's and the dog's body - hairy and hairless, big and small, naked and dressed, playing, embracing, gazing at each other and their implosion in the scenery, the environment depicted in the images - are underscored in the photographs from the Carpe Fucking Diem series. In this point of view, connections between beings are emphasized and the division of nature and culture appears to be overly simplified.

4 Also, the study "Exposure to household pet cats and dogs in childhood and risk of subsequent diagnosis of schizophrenia or bipolar disorder" suggests that living with pets as a child causes alteration in the human microbiome and among other factors decreases the hazard of having a subsequent diagnosis of schizophrenia (Yolken, Stallings, Origoni, Katsafanas, Sweeney, Squire \& Dickerson 2019). I mention this as a side note related to the concrete, physical relationship between companion species (Yolken et al. 2019). 


\section{The asymmetrical relationship between "the pet and the owner"}

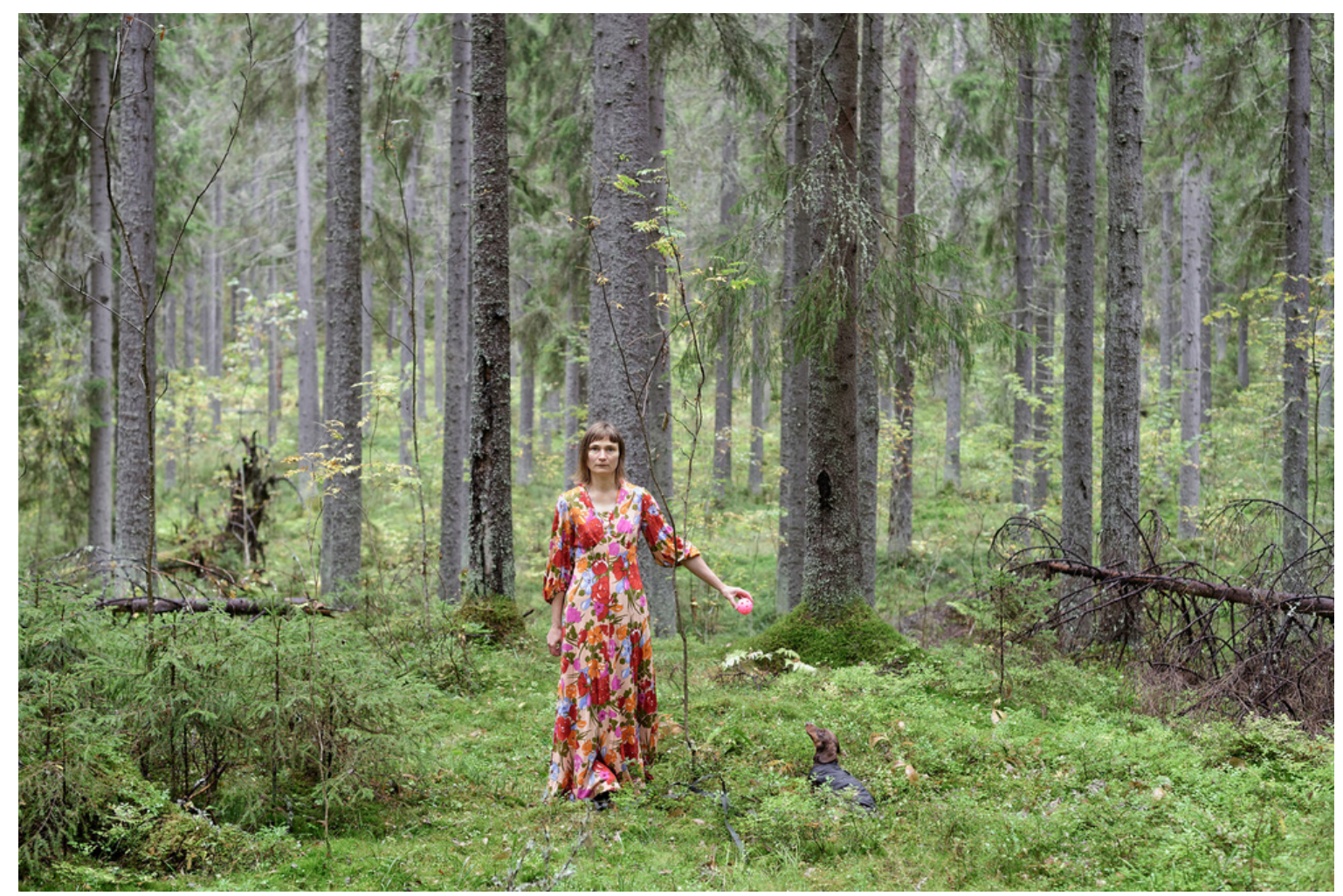

Figure 2. Elina Brotherus, Marcello's Theme, 2014, photograph $(90 \times 135 \mathrm{~cm})$.

In the self-portrait entitled Marcello's Theme (2014) (Fig. 2), Elina seems at first glance to be the central figure; she is looking straight into the camera while wearing a colorful floral dress in the middle of a forest. However, I have decided to focus on Marcello here, towards whom Elina's hand is pointing, and after whom the artwork has been named. With his short feet he is barely visible from the undergrowth of what seems to be a Finnish forest. He is wearing a black coat and is staring intensely at the ball in the human's hand. There is also a leash under the human's foot to ensure the dog will not run away to hunt and track wild animals. ${ }^{5}$

The leash is associated with the asymmetrical relationship between the pet and the owner. The word "pet" constructs animals in a specific way. The word originates from the eighteenth century referring to a hand-reared lamb, but today it is used to describe all non-working domestic animals living with humans. "Pet" can also refer to

5 Humans originally bred dachshunds to scent, chase and flush out badgers and other burrowdwelling animals such as rabbits. 
"an indulged, spoiled, or favorite child" (Fudge 2008, 88) and can accordingly refer to the animals' infantilization and their inferior status. Also, calling an animal a "pet" could be regarded as reinforcing the dominance many researchers recognize as being fundamental to all human-pet relations (Fudge 2008, 88). To avoid such aspects, Donna Haraway proposes the more heterogeneous category "companion species", that include "rice, bees, tulips and intestinal flora, all of whom make life for humans what it is - and vice versa" (Haraway 2003, 15).

Erica Fudge argues in her book Pets (2008), that there has been a recent shift in scholarship where researchers have increasingly started to recognize the importance of relating to animals in a more diverse manner. Fudge $(2008,4)$ suggests that this derives from, for instance, the awareness of the environmental crisis and the growing understanding of humans' genetic closeness to animals (Fudge 2008, 4). Human-animal relations are common themes in today's visual culture, and non-human animals are often included in portraits and self-portraits. Artists draw human attention to issues such as the sixth mass extinction and compassion towards animals while "the problem of embodying another perspective" (Broglio 2011, XV) intrigues art. ${ }^{6}$

Animals have functioned as symbols and illustrated myths and beliefs in the visual arts for millennia. Pets may have been represented as individuals, but wild animals have been mostly depicted as exemplars and symbols of their species. Commonly, animals are interpreted as symbols of human activity and interaction (see Baker 2002, 68-69; Burt 2002, 11; Salmia 2018). Living with non-human animals on a daily basis challenges the Cartesian notion of the animal-human divide. The intimacy between species allows the individuality of non-humans to be recognized. Leslie Irvine argues that the intimate nature of the relationships between pets and their humans, and everyday practices of interaction, physical closeness, play and communication can question hegemonic views of animals as "other" and protest against society's disregard for non-human life (Irvine 2001, 152; see also Fox 2006, 534).

Bodies and words, stories and worlds, combine in naturalcultural companion species. A dog is not a symbol or an alibi for other themes, but rather "fleshy material-semiotic presences in the body of technoscience" (Haraway 2003, 5). In Marcello's Theme, Elina recognizes the fact that the viewer will be looking at her, but Marcello is not in the forest as a symbol in the photograph, or for me (the viewer), to look at him. Holding the ball in her hand and the leash under her foot to persuade Marcello to stay

6 For instance, Mary Britton Clouse has attempted to revolutionize attitudes towards chicken, one of the most undervalued animal species, with her self-portraits where human and chicken faces can be seen to blend into a human-animal hybrid (Potts, 2009). 
within the frame, Elina is looking straight into the camera with a serious expression while Marcello is staring impatiently at her waiting for the playing to start. Hence, I see the inter-subjectivity in this image as becoming worldly and more attentive towards the demands of a significant other (Haraway 2003, 61).

Haraway $(2008,67)$ argues, living with each other transforms both the dog and the human. Consequently, "actual encounters are what make beings" (Haraway 2008, 67). Haraway's notion of inter-reliance - of human existence only as a companion species - opens up an unusual way of thinking about human-pet relationships (Haraway 2003, 20-21). Elina seemingly persuades Marcello with a ball to stay within the frame of the photograph emphasizing that he is not a mere prop in the photographs, but has a will and agency of his own. Thus, the embodied consciousness of the dog questions the very logic of photographing encounters. I see animal agency as especially fascinating from the point of view of the very human-centered genre of self-portraits. A human may attempt to express a certain quality with a self-portrait, but will the animal willingly co-operate? The animal subject's body is not something that follows the photographer's instructions perfectly, or something that is inspired by the same motives. A human can plan an image and try to persuade the dog to follow this vision, but the end result depends on both of their embodied agencies and their "co-constitutive natural cultural dance" (Haraway 2008, 27). Accordingly, the photographic composition of Marcello's Theme not only depicts a dog and a human, but more importantly depicts the relationship between them as unpredictable and complex, taking shape in the embodied subject-making between species.

\section{5 "All animals are equal, but some animals are more equal than others"}

"Beings do not preexist their relatings" Haraway argues - rather, they constitute each other and themselves through their reaching into each other (Haraway 2003, 6). According to Fudge $(2008,3)$, living with an animal encourages a rethinking of what it means to live, and suggests, based on Edmund Leach's study (1966), that the pet is a boundary breaker, a "man-animal." Pets have crossed over from outside to inside and they are with humans at home, while all other animals live outside (and the only other ones that make it indoor are labelled "vermin"). Pets also figuratively break down the distinction between inside and outside because they are simultaneously like us and not like us (Fudge 2008, 17-18). The act of naming pets "implies that these animals are

7 Orwell [1945] 2008, 90. 
going to be given special treatment and that individual attributes or personalities are likely to be claimed for them" (Beck \& Katcher 1996, 11-12). Human family members often develop attachments towards their animal and come to consider him or her as a family member. The relationship with the pet becomes materialized through signs such as "leashes, collars, physical contact, mutual gaze, and through the retelling of a shared history" (Irvine \& Cilia 2016, 3-4; Sanders 1999 \& 2003).

In the photographic version of Marcello's Theme, Marcello is separated from nameless wild animals and associated with the world of humans also through clothing. Crossing the fields of visual culture and consumption studies, Annamari Vänskä $(2018,23)$ writes about the role of garments in the process of becoming human. As Vänskä $(2018,25)$ explains, the dog has transformed from an animal to a pet, emerging as an entity in which education, consumerism and fashion intersect. Since the 19th century, with the rise of industrialism, evolutionary theory and breeding, the dog has been transformed into a "pet", which simply means the process of separating the dog from other animals. Like a middle-class child, a middle-class pet dog needed to be educated to behave well. The logic of dressing dogs was the same as with children: to "embourgeoise the beast", to remove unwanted animal-like features and to replace them with desirable human traits (Vänskä 2018, 25). Dressing dogs was a part of "humans' middle-class performance" and today garments are tools with which to emphasize belonging to the same pack, mark the dog as a family member, and signify the similarity between humans and dogs (Vänskä 2018, 26). With his sporty black jacket protecting him from the cold and the rain, Marcello is a naturalcultural hybrid in the photograph (Fig. 2), embodying and disrupting attributes considered natural (animals) and cultural (clothes).

The video work with the same title, Marcello's Theme (2015) (Fig. 3), starts with the Marcello's Theme photograph being taken while Marcello is barking and demanding the ball in slow motion while wagging his tail intensely. This is followed by a scene showing Marcello weaving his way through a meadow, and even though the grass is taller than him and I mostly only see the plants moving and at times nothing more of Marcello than his wagging tail, I get a glimpse of how it might feel to be a young dog, jumping and running effortlessly with the grass touching one's sides. The next scene shows Marcello playing with a milk carton in a parking lot next to a highway and is followed by a view of Elina sitting quietly in front of a dead fox, presumably found by Marcello, while the video's accordion music becomes increasingly slower and sadder. 

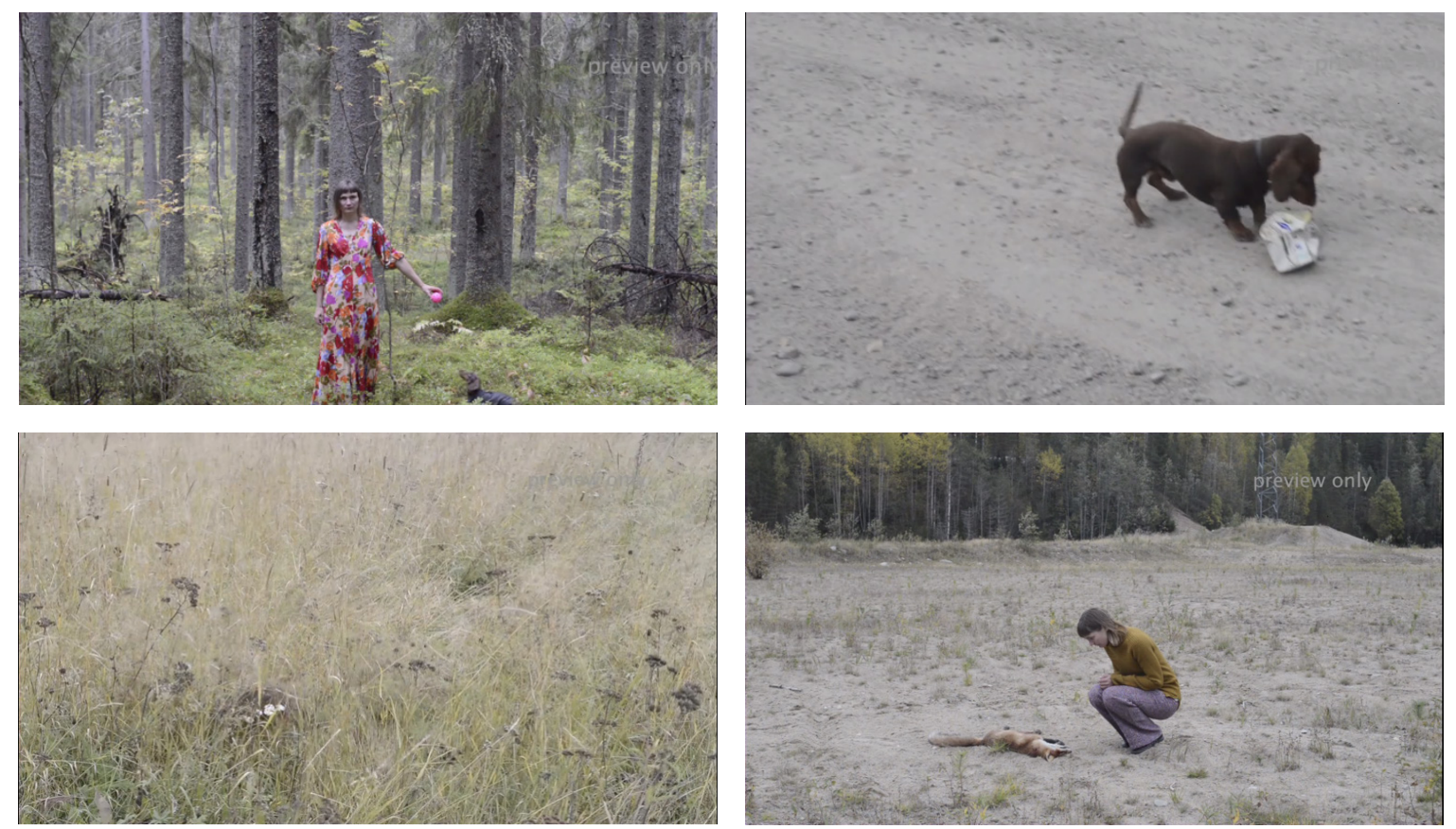

Figure 3. Elina Brotherus, Marcello's Theme, 2015, still shots from the video work.

I feel that Marcello playing with the container of another species' milk and the fox that has died violently, both function as reminders of cultural ambivalence towards animals. According to Irvine and Cilia $(2016,2)$, this ambivalence conveys the fact that although certain species are allowed into human homes and on human beds, others are only considered useful as food, while yet others are treated as vermin, deserving only scorn and extermination. Multispecies kinship contains several paradoxes related to the hierarchical power structures between humans and animals: we love our significant others from a different species, recognize their subjectivity and are concerned about their wellbeing, while simultaneously feeding the bodies of other animals to them.

As Braidotti $(2013,68)$ argues, "the oedipal relationship between humans and animals is unequal and framed by the dominant human and structurally masculine habit of taking for granted free access and the consumption of the bodies of others, animals included". According to her, the problematic relationship between humans and animals is linked to the market economy and labour force (Braidotti 2013, 70). Animals are exploited for hard labor and constitute an industrial resource in themselves. They are all inscribed in the market economy that commodifies them and makes them equally disposable (Braidotti 2013, 70-71). Humans paired off wolves to get puppies that were better suited as watch dogs and hunters. The breeding was continued to achieve large dogs and small dogs, dogs to herd sheep and dogs to hunt badgers. Today, almost 400 dog-breeds exist in different sizes, colors and shapes. Breeding has caused serious 
health problems in dogs such as respiratory problems, skin problems, joint problems, hair loss and infertility (Koskela 2017, 87-88). Accordingly, emotional closeness with animals does not necessarily break the human-animal binary. Those animals that are considered family members also face the asymmetrical reality of human-animal relationships: humans have the power to decide the animals' fate by leaving them alone all day, controlling their movements, outdoor and indoor access, when and what they eat, and when they defecate and urinate. Finally, their lives can be ended for instance in case of illness or if their behavior fails to meet expectations (Irvine \& Cilia 2016, 2).

Irvine and Cilia (2016) suggest recognizing that families are, and always have been, more-than-human. Thinking in this way requires abandoning the concept of "family" as a pre-constituted entity and taking up the notion of "becoming with". Morethan-human families represent a hybrid that includes multiple relations of humans and animals, and the social and natural (Irvine \& Cilia 2016, 8). For instance, in my own more-than-human family, my child learned how to bark before speaking any human words. Her obscure conceptions of the boundaries between non-human animals and humans, so clear to adults, makes me question my perceptions daily.

Human-led multispecies families reinforce the asymmetrical human-animal relations by deciding the destinies of animals, controlling them, buying pure-bred animals, and by hierarchically valuing animal species (which ones to eat and which ones to cherish). However, living with an animal can inspire humans to pay attention to and problematize such hierarchies. Haraway sees partial recuperation and getting on together with multispecies players on a vulnerable and wounded earth as a way of "staying with the trouble" (Haraway 2016, 10). The concept of "Chthulucene"8 emphasizes recognizing environmental disasters and the concerns they raise, but also that we should act responsibly with non-human others. "Staying with the trouble" spurs us to find solutions in the middle of problematic connections, recognizing the effects of our actions and taking non-human others into consideration in everything we do (Hyvärinen et al. 2017, 2).

For Haraway $(2003,7,61)$, it is essential to become more worldly and respectful, make more livable worlds together with companion species and explore loving each other less violently. In the Marcello's Theme video, Elina stops in front of the dead fox on

8 Haraway defines the concept of Chthulucene in her book Staying with the Trouble (2016) as a timescape after or instead of the Anthropocene and Capitalocene. Chthulucene is a radical way of reconceptualizing the world based on processes and connections between creatures from different species. According to Haraway it is essential to learn to stay, write and think with the trouble, with the visions of apocalyptic futures while simultaneously dealing with the past (Haraway 2016, 1-5; Rojola 2017, 86) 
a field just seconds after her young and lively dog Marcello has been depicted playing in another field. Both animals' unique lives are accentuated in the video, suggesting that subjectivity is not solely reserved for humans.

\section{The ongoing story of co-evolution}

I find it remarkable that we hear the dog's voice and see his movements at the beginning of the Marcello's Theme video, while the human keeps still and quiet. The human's silence is intriguing in particular because the lack of verbalized human language is one of the key criteria for justifying the distinction between humans and animals. Psychology professor, neuropsychology researcher and dog-human communication specialist Stanley Coren (2001) asserts that a long line of researchers following René Descartes have suggested human species to be special in terms of linguistic ability. Descartes made the well-known proposition that non-human animals are simply furry machines and that no animals but humans have consciousness or higher mental abilities. To test the consciousness of animals, one should test their ability to create spoken human language (Coren 2001, 14-15; see also Fudge 2008, 61-63). ${ }^{9}$ However, as Haraway points out, dogs and humans living together train each other in communication, and meet the other in all their fleshy detail (Haraway 2003, 2, 34-35). I presume Elina understands what Marcello is communicating in the video quite well, although he does not use human words ("Throw the ball already"). Verbal communication is only a minor element in a dog-human relationship.

Haraway (2003) argues that when discussing canine evolution in Western discourse, what is actually discussed is the relation between what counts as nature and what counts as culture, and the correlated issue of 'who' and 'what' count as an actor. Domestication is often interpreted as a one-sided, human-led operation, where man creates his tools, the domestic animals. Studies of dog mitochondrial DNA indicate the divergence of dogs from wolves as long as 150000 years ago - at the origins of Homo sapiens sapiens. Humans and dogs have co-evolved and shaped each other throughout their mutual history and the association with dogs has changed human life ways remarkably (Haraway 2003, 27-31).

Sociologist and philosopher Bruno Latour (2004) sees the division created be-

9 However, almost every animal on this planet has a communication or signaling system. For instance, the honeybee has evolved a method of communicating with "dancing" movements conveying information about the direction and quality of the food the bees have found. (Coren 2001, 15-16) 
tween nature and society as the largest problem in Western thinking. The main idea in his "political ecology" is to extend the concept of democracy to non-humans. As he explains, the division between nature and society, subjects and objects, and facts and social representations should be abandoned (Latour 2004, 50-51; see also Lummaa 2014 , 98). Furthermore, Jacques Derrida notes that when his cat looks at his naked body in the morning in the bathroom, he is on passive display and turns from a subject into an object under the animal's observation (Derrida [2006] 2019, 28). Similarly, the self-portrait and video work entitled Marcello's Theme crosses the hierarchical constructions of the gaze; although Elina has designed and executed the photograph and the video, she is a silent object of the viewer's and the animal's gaze. Unconventionally, the video also proposes with its title that the animal is the subject of the story: this is Marcello's theme and Marcello plays the main part in it. To me, the typical asymmetrical relationship between a human and a dog, often visible in self-portraits, is replaced by a vision of a less hierarchical reality.

\section{Multispecies love stories}

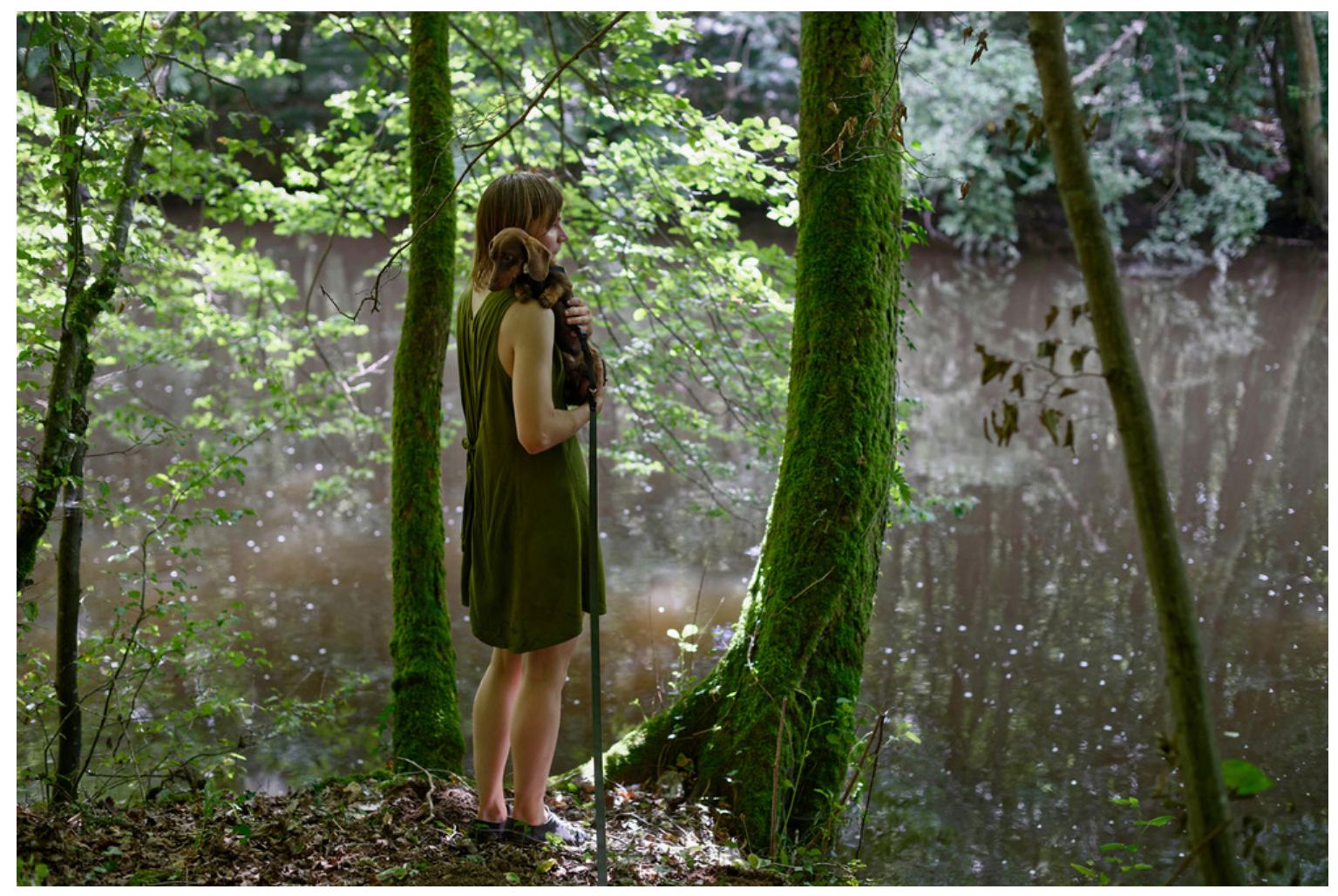

Figure 4. Elina Brotherus, Silver River, 2014, photograph (70x105 cm). 
In another photograph in the same series called Silver River (2014) (Fig. 4), Elina holds Marcello in her arms by the glistening riverside of Silver River. This self-portrait shows how intimate and embodied "lived intersubjectivity", "of two beings sharing a messy, awkward, loving relationship" (Fox 2006, 535), challenges human-centered definitions of subjectivity and family. Elina has a tender expression on her face and Marcello's ears are pulled back gently in a friendly manner. The color of Elina's dress is very similar to the mossy green trunks of the trees surrounding them, and the composition makes the standing couple blend into the environment.

One detail in Silver River has puzzled me enormously. It appears to be something that Roland Barthes ([1980] 2000, 27) refers to as "punctum": a detail that disturbs and stings me in the photograph. I have stared at the photograph for hours trying to decide if the line in the middle of the image is a camera shutter release cord or a dog leash. Trying to understand this detail, I have enlarged the picture on the screen of my laptop until I only saw unclear pixels. I have compared the photograph to self-portraits where Elina has left the shutter release cord visible, and to images where it is possible to see Marcello's leash. Finally, I concluded that it must be the dog leash. I find this particularly interesting, as Elina has previously used a shutter release cord to emphasize that the photographer and the model are the same person in her work (see Mora 2016; Nyberg $2003,143)$. Similarly, the leash is emphasized visually in this photograph, it is attached to Marcello, leads in the middle of the image behind the camera, and attaches the human-animal couple to the viewer.

While looking at the photograph, I can nearly feel the warmth of the two bodies embracing each other. The photograph touches me and brings tears to my eyes. After my dog's death, the absence of a small, warm, furry creature pressing herself against my feet when I sleep, work or sit on the sofa, has changed the sounds, smells and atmosphere of our home. The dog leash virtually lands in my hand, when looking at the photograph, making me feel like I am invited to receive consolation, closeness and care between species. The earthy colors - the moss green of Elina's dress and in the trees surrounding them, along with the different shades of brown on the ground as well as on the river - make me feel that we are in the same "hot compost pile" of the fleshy details of a mortal relationship, living and dying with each other, in connection to and requiring one another (Haraway 2016, 4).

In retrospect, my dog taught me much more than I ever could teach her. She was house-trained, stayed passably in the yard, and knew some tricks to get doggietreats, while I became aware of the subjectivity and individuality of a different speciesmember. Because of this, I came to re-evaluate my habits and attitudes related to other 
non-humans as well. In fact, people who share their households with companion animals also tend to express greater concern for farmed animals and greater belief in the mental capacities of animals (Kupsala 2019, 58). Touching, becoming with and looking back make species co-shape each other in complex ways (Haraway 2008, 36). In Silver River, the embodied relationship between companion species is made both visible and palpable.

Furthermore, Haraway (2016) stresses that in order to stay with the trouble in troubling and turbid times, it is required to make "oddkin" rather than, or in addition to, the biogenetic family. We require each other in companion species collaborations and we become-with each other, or not at all (Haraway 2016, 1-2, 4). A more-thanhuman family creates hope for the future, reaching towards other species in an attempt to understand and question human superiority. In the Carpe Fucking Diem series, the intimacy of living with a non-human family member, and the willingness to understand a creature from another species, is depicted in a way that challenges the viewer to feel with that intimacy.

\section{Conclusions: "Happy (more-than-human) families are all alike; every un- happy family is unhappy in its own way"}

Despite the fact that pets continue to be potent props for heteronormative kinship, the presence of dogs and cats have also challenged normative family forms, evolving human families into "more-than-human packs" (McKeithen 2017, 123). Friendship, company and shared activities are built on close feelings and emotions expressed by both humans and animals, and result in the hybridization of the family (Franklin 2006, 142). In all of the materials discussed above, Elina and Marcello are outdoors: standing in front of a wooden wall, in a forest, or on a riverside. I feel that this emphasizes the outsider point-of-view of the conventional heteronormative, human-centered family happiness and depicts an experience of non-belonging (Phu et al. 2017, 157). Questioning the norms of a human nuclear family opens the possibility for something new, a more-than-human family.

Even though the works I have discussed from the Carpe Fucking Diem series are taken by the artist of herself, they do not study human subjectivity alone. In this article, I argue that such self-portraits - in which multispecies family members constitute each other - can destabilize the boundaries of the subject and object, and question the anthropocentrism of the normative family. The series resonates powerfully with topical issues in today's society: alternatives to conventional family forms, close connections 
with non-human others, childlessness and recovering on a wounded planet where new human children must be "rare and precious" (Haraway 2016, 138).

From another viewer's perspective, these photographs may only appear as beautiful artworks about the artist and her dog; however, for me, the powerful, affective encounters with these artworks have evoked the physical, concrete nature of sharing one's life with a creature from another species. Artworks, such as the photographs and the video work from the Carpe Fucking Diem series, have the possibility to suggest new perspectives on interspecies relations, and to prompt human viewers to ponder on their own human-animal relations as well as the hierarchies that are made and unmade through them.

Happy little Marcello has, in this article, shown me the way from his human's lap to more-than-human and queer family relations as well as through forests and meadows to a dead fox, pointing to hierarchies between species. Finally, he has ended back in Elina's embrace, emphasizing the embodied connections and entanglements among creatures living on earth, collaborating in unexpected ways and depending on one another.

\section{ACKNOWLEDGEMENTS}

I would like to thank Katve-Kaisa Kontturi, Katariina Kyrölä and Tutta Palin for their patient reading of, and fruitful comments on, early drafts of this article. Warm thanks also to Trace's editors and three anonymous referees for their suggestions and criticisms, all of which made this a better text. Also, thank you Elina Brotherus for allowing me to use the photographs. I would like to dedicate this article to my best friend Dada, whom I lost during the writing process.

\section{References}

\section{WEBSITES}

Brotherus, Elina. n. d. "Carpe Fucking Diem.” Accessed March 4, 2021. http://www. elinabrotherus.com/photography\#/carpe-fucking-diem/.

Brotherus, Elina. 2015. "MARCELLON TEEMA / Marcello's Theme." Video, 6:12. https:// vimeo.com/148887202.

Marcello (@marcello_the_flying_dachshund). n. d. Instagram account. Accessed March 4, 2021. https://www.instagram.com/marcello the flying dachshund/.

Mora, Gilles. 2016. "The Double Perspective." Translated by Damien Rembert on Elina 
Brotherus Webpage. Accessed June 29, 2020. http://www.elinabrotherus.com/ texts/2016/8/25/the-double-perspective-gilles-mora .

Potts, Annie. 2009. "Mary Britton Clouse - For the Wonderful Chicken - An Animal Rights Article from All-Creatures.org." All-Creatures.org. https://www.all-creatures. org/articles/ar-mary.html

\section{NEWS ARTICLES}

Martelius, Katja. 2018. “Muusa muotokuvassa." Helsingin Sanomat, September 9, 2018. https://www.hs.fi/sunnuntai/art-2000005818848.html.

\section{LITERATURE}

Alaimo, Stacy. 2008. "Trans-Corporeal Feminisms and the Ethical Space of Nature." In Material Feminisms, edited by Stacy Alaimo and Susan Hekman, 23-46. Bloomington: Indiana University Press.

Baker, Steve. 2002. “What Does Becoming-Animal Look Like?” In Representing Animals, edited by Nigel Rothfels. Bloomington and Indianapolis: Indiana University Press.

Barad, Karen. 2003. "Posthumanist Performativity: Toward an Understanding of How Matter Comes to Matter." Signs 28, no. 3: 801-31.

Barrett, Estelle. 2013. "Materaility, Affect, and the Aesthetic Image." In Carnal Knowledge: Towards a "New Materialism" through the Arts, edited by Estelle Barrett and Barbara Bolt, 63-72. London and New York: I. B. Tauris \& Co.

Barthes, Roland. [1980] 2000. Camera Lucida. London: Vintage.

Beck, Alan M., and Katcher, Aaron. 1996. Between Pets and People: The Importance of Animal Companionship. Lafayette, IN: Purdue University Press.

Bernardes, Jon. 1999. "We Must Not Define 'The Family'!” Marriage \& Family Review, 28, no. 3-4: 21-41. https://doi.org/10.1300/J002v28n03 03.

Bolt, Barbara. 2013. "Introduction: Toward a 'New Materialism' through the Arts." In Carnal Knowledge: Towards a "New Materialism" through the Arts, edited by Estelle Barrett and Barbara Bolt, 1-13. London and New York: I. B. Tauris \& Co.

Braidotti, Rosi. 2013. The Posthuman. Cambridge and Malden: Polity Press.

Braidotti, Rosi. 1994. Nomadic Subjects: Embodiment and Sexual Difference in Contemporary Feminist Theory. New York: Columbia University Press.

Bright, Susan. 2010. Auto Focus: The Self-Portrait in Contemporary Photography. New York: Monacelli Press. 
Broglio, Ron. 2011. Surface Encounters: Thinking with Animals and Art. Minneapolis and London: University of Minnesota Press.

Brotherus, Elina. 2015. Carpe Fucking Diem. Heidelberg \& Berlin: Kehrer.

Burt, Jonathan. 2002. Animals in Film. London: Reaktion Books.

Butler, Judith. 2002. "Is Kinship Always Already Heterosexual?" Differences - A Journal of Feminist Cultural Studies 13, no. 1: 13-44.

Coren, Stanley. 2001. How to Speak Dog: Mastering the Art of Dog-Human Communication. New York: Fireside.

Dahl, Ulrika and Gunnarsson Payne, Jenny. 2014. "Introduction: (Re)thinking Queer Kinship and Reproduction." lambda nordica 3-4: 11-27.

Dahl, Ulrika. 2014. "Not Gay as in Happy, but Queer as in Fuck You: Notes on Love and Failure in Queer(ing) Kinship." lambda nordica 3-4: 143-168.

Derrida, Jacques. [2006] 2019. Eläin joka siis olen. Translated by Anna Tuomikoski. Helsinki: Tutkijaliitto.

Fox, Rebekah. 2006. "Animal Behaviours, Post-Human Lives: Everyday Negotiations of the Animal-Human Divide in Pet-Keeping." Social \& Cultural Geography 7: 525-537. https://doi.org/10.1080/14649360600825679.

Franklin, Adrian. 2006. "'Be[a]ware of the Dog': A Post-Humanist Approach to Housing." Housing, Theory and Society 23, no. 3: 137-156.

Fudge, Erica. 2008. Pets. Stocksfield: Acumen.

Halberstam, Judith. 2011. The Queer Art of Failure. Durham and London: Duke University Press.

Haraway, Donna. 2016. Staying with the Trouble: Making Kin in the Chthulucene. Durham and London: Duke University Press.

Haraway, Donna. 2008. When Species Meet. London and Minneapolis: University of Minnesota Press.

Haraway, Donna. 2003. The Companion Species Manifesto. Chicago: Prickly Paradigm Press.

Haraway, Donna. 1991. Simians, Cyborgs, and Women: The Reinvention of Nature. New York: Routledge.

Hyttinen, Elsi, and Karoliina Lummaa. 2020. “Lukeminen humanismin murroksessa.” In Sotkuiset maailmat: Posthumanistinen kirjallisuudentutkimus. Jyväskylä: Nykykulttuuri.

Hyvärinen, Pieta, Sari Irni, Katariina Kyrölä, and Marja Vehviläinen. 2017. "Luontokulttuurit feministisessä tutkimuksessa.” Sukupuolentutkimus -Genusforskning 30, no. 


\section{2: $2-5$.}

Irvine, Leslie, and Laurent Cilia. 2016. "More-than-human families: Pets, people, and practices in multispecies households." Sociology Compass 2: 1-13. https://doi. org/10.1111/soc4.12455.

Irvine, Leslie. 2001. "The Power of Play." Anthrozoos 14: 151-160.

Kontturi, Katve-Kaisa. 2006. Feminismien ristiaallokossa: Keskusteluja taiteen ja teorian kytkennöistä. Turku: Eetos.

Koskela, Tarja. 2017. "Jalostus." In Uusi eläinlaki, edited by Mai Kivelä, Veikka Lahtinen and Laura Uotila, 79-88. Helsinki: Into.

Kupsala, Saara. 2019. A Sociological Study of Finnish Attitudes, Perceptions and Meanings Regarding Animals in Food Production. Joensuu: Publications of the University of Eastern Finland. Dissertations in Social Sciences and Business Studies., no 199. http:// epublications.uef.fi/pub/urn isbn 978-952-61-3118-4/urn isbn 978-952-613118-4.pdf.

Latour, Bruno. [1999] 2004. Politics of Nature: How to Bring the Sciences into Democracy. Translated by Catherine Porter. Cambridge and London: Harvard University Press.

Le Moignan, Effie, Shaun Lawson, Duncan A. Rowland; Jamie Mahoney, and Pam Briggs. 2017. "Has Instagram Fundamentally Altered the 'Family Snapshot'?" CHI 2017: 4935-4947. https://doi.org/10.1145/3025453.3025928.

Leach, Edmund. 1966. "Anthropological Aspects of Language: Animal Categories and Verbal Abuse." In New Directions in the Study of Language, edited by E. H. Lenneberg, 151-165. Cambridge, MA: MIT Press.

Lehikoinen, Elli. 2017. “'Olen nisäkäs. Tuotan maitoa.': Ihmisen lajius ja lisääntymisprosessi 2000-luvun kotimaisessa kirjallisuudessa." Sukupuolentutkimus - Genusforskning 30, no. 2: 21-33.

Leppänen, Taru. 2018. "Always More Than Two: Vibrations, the Foetus, and the Pregnant Person in Childbirth Singing Practices." NORA-Nordic Journal of Feminist and Gender Research, 26, no. 2:99-111. https://doi.org/10.1080/08038740.2018.146 $\underline{2255}$.

Lummaa, Karoliina. 2014. "Runous, ei-inhimillinen ja edustamisen politiikka." In Toisin sanoin - Taiteentutkimusta representaation jälkeen, edited by Ilona Hongisto and Kaisa Kurikka, 79-109. Turku: Eetos.

McKeithen, Will. 2017. "Queer Ecologies of Home: Heteronormativity, Speciesism, and the Strange Intimacies of Crazy Cat Ladies." Gender, Place \& Culture 1: 122-134. https://doi.org/10.1080/0966369X.2016.1276888.

Mättö, Vilma. 2019. "Honeybees and Animal Narratives (Overview of the (Un)Common Worlds Art Programme)." Trace: Journal for Human-Animal Studies 5: 116-120. 
Nyberg, Patrik. 2003. "Valokuva maalauksena: Elina Brotheruksen siveltimenjälki." In Volare: Intohimona taide, edited by Erkki Anttonen, Anne Aurasmaa, Arja Elovirta, Heikki Hanka, Liisa Laajoki and Johanna Vakkari, 138-148. Helsinki: Taidehistoriallisia tutkimuksia 26.

Orpana, Jennifer, and Parsons, Sarah. 2017. "Seeing Family." Photography and Culture, 10, no. 2: 95-98, https://doi.org/10.1080/17514517.2017.1337853.

Orwell, George. 2008 (orig. 1945). Animal Farm. London: Penguin Books.

Phu, Thy, Brown, Elspeth H. and Dewan, Deepali. 2017. "The Family Camera Network." Photography and Culture, 10, no. 2: 147-163. https://doi.org/10.1080/17514517 .2017.1327562.

Rojola, Lea. 2017. "Book Review: Ajattelua lankaleikeillä. Staying with the Trouble: Making Kin in the Chthulucene." Sukupuolentutkimus -Genusforskning 30, no. 2: 85-88.

Rojola, Lea. 2012. "Juokse lujaa, pure kovaa!: Donna Harawayn kumppanuuslajit ja feminismi." In Erot ja etiikka feministisessä tutkimuksessa, edited by Kirsti Lempiäinen, Taru Leppänen and Susanna Paasonen, 256-277. Turku: Utukirjat.

Salmia, Tiina. 2018. "Monkey in the Self-Portrait: The Non-Human Animal and the Question of Self-Representation." WiderScreen 3.

Sanders, Clinton R. 1999. Understanding Dogs: Living and Working with Canine Companions. Philadelphia: Temple University Press.

Sanders, Clinton R. 2003. "Actions speak louder than words: Close relationships between humans and nonhuman animals." Symbolic Interaction, 26: 405-426.

Yolken, Robert, Cassie Stallings, Andrea Origoni, Emily Katsafanas, Kevin Sweeney, Amalia Squire, and Faith Dickerson. 2019. "Exposure to household pet cats and dogs in childhood and risk of subsequent diagnosis of schizophrenia or bipolar disorder." PLoSONE 14, no. 12: 1-15. https://doi.org/10.1371/journal.pone.0225320.

Vänskä, Annamari. 2018. "How to do Humans with Fashion: Towards a Posthuman Critique of Fashion”. International Journal of Fashion Studies 1: 15-31.

Weeks, Jeffrey, Brian Heaphy and, Catherine Donovan. 2001. Same Sex Intimacies: Families of Choice and Other Life Experiments. London: Routledge.

Weston, Kath. 1991. Families We Choose: Lesbians, Gays, Kinship. New York: Columbia University Press. 